\title{
Barrenness between Mr. and Mrs. Ramsay: Fillmore's frame Study of Virginia Woolf's to the lighthouse
}

\author{
Dr. Vagisha Mishra
}

Assistant Professor, Amity School of Languages, Amity University Chhattisgarh, India

Received: 18 Jun 2021; Received in revised form: 09 Jul 2021; Accepted: 16 Jul 2021; Available online: 23 Jul 2021

C2021 The Author(s). Published by Infogain Publication. This is an open access article under the CC BY license (https://creativecommons.org/licenses/by/4.0/).

\begin{abstract}
In To the Lighthouse, we find scantiness in matrimony which does not permit mature rational exchange of thoughts and emotions. The trajectory of suffocating wedlock through Woolf's oeuvre is heightened in the novel when both Mr and Mrs Ramsay acknowledge the precincts of their nuptials. In their stillness, they want definite barriers to be upheld just like Virginia Woolf and Leonard Woolf. The paper attempts to underline the lexical expressions which Woolf herself quoted in her diaries and letters, thereafter making Mr and Mrs Ramsay mouthpiece for her ideas on conjugal relationships as an attempt to vindicate her behaviour with Leonard Woolf.
\end{abstract}

Keywords - Semantic Analysis, Fillmore's Frame Semantics

\section{INTRODUCTION}

Language is the mirror of a person's psyche. The selection of words and phrases by anyone helps us to understand the possible facts through possible meaning, alongside understanding the psychology of the author or speaker. This also helps us to understand the contextual factors and underlines the idea of how language relates to the mind at large. The linguistic and philosophical study of meaning, semantics reflects the thought process of a speaker. When To the Lighthouse is analysed semantically we find various voices which underline the discontentment within nuptial relationships.

Throughout 1908 and 1909, Woolf was frequently advised to get married. At twenty-seven, Woolf was precariously close to becoming a spinster. Despite of receiving several proposals, Woolf did not want to settle down with someone who would dominate her with intellect or power. As a woman who hailed from a reputable class in her society, she could not deny Leonard Woolf when he proposed to her for marriage. As a Jew, Leonard Woolf already ranked beneath the class from which Virginia Woolf belonged; furthermore Leonard Woolf being fairly different from the masculine prototype of her class, she knew she could easily gain power over him along with eradicating her spinsterhood tag.

The discontentment with marriage and the responsibilities or experiences it brings along with itself is shown persistently in the forms of negative locution, the poignancy of marriage is heightened in To the Lighthouse when Mr and Mrs Ramsay find it very difficult to communicate or appreciate each other despite of living under the same room.

Concerning Mrs Ramsay's portrayal as a woman, she is presented to the readers as the anti- heroine of the author herself. Whereas Virginia Woolf is celebrated for her feminist stance, it seems that Mrs Ramsay embodies the entire contrary traits. Portrayed as a traditional woman in terms of late Victorian stereotypes, Mrs Ramsay lives in a male milieu and strives hard to highlight herself as the best version of a wife contended with her domestic power. A woman reasonably faithful to Victorian values, she demonstrates it by protecting all the strong characters when she herself is the weakest in reality. Evidently Woolf uses the characterization of Mrs Ramsay with the intention of being sarcastic about the dominant conceptions with respect to gender from women themselves. 


\section{THE PLOT}

Mrs. Ramsay works hard to be an angel in the house, "the women that men wished" to have (p.298) by providing full fledged support to patriarchal values and bearing children. In order to strengthen her role as an angel of the house, she sacrifices at times and complies with the patriarchal code of conduct. In exchange she is revered and raised to pedestal by being identified to the image of Virgin Mary. While Mrs. Ramsay attempts to adhere to patriarchal code of conduct, she finally succumbs after attempting to control her husband Mr. Ramsay, implying that a woman who desires or even attains power is unnatural and must be castigated before the society.

Although Mrs. Ramsay wants everyone to get into wedlock, she herself is in a marriage that none of the character holds upon as her ideal. Traces of hypocrisy are evident in her interaction with her husband. Just like Virginia Woolf and Leonard Woolf, we see recurrent pressure between Mr Ramsay's logical undertakings and Mrs Ramsay's familial ecstasy.

"It annoyed her, this phrase-making, and she said to him, in a matter of fact way, that it was a perfectly lovely evening. And what was he groaning about, she asked, half laughing, half complaining, for she guessed what he was thinking - he would have written better books if he had not married." (To the Lighthouse, p.335)

Throughout the novel, we see Mrs Ramsay being subordinated to Mr Ramsay's needs, engulfed by his world. Just like other heroines of Woolf's novels, we see Mrs Ramsay being crippled by her tapered edification, trained and brought up to be rationally substandard to men. Nonetheless, when the power play is reversed in the latter part of the novel, the only thing that narrative serves in the development of the plot is to make Mrs Ramsay die. As the story progresses, it is interesting that we do not find any significant dialogue interchange between the protagonist husband and wife, "But he could not speak to her. He could not interrupt her.” (p.332)

\section{THE PERVADING SYMBOL OF "BARRENNESS"}

Woolf deliberately seems to portray Mr Ramsay as exclusively dependent on his wife, self- centred and immature as he demands attention and comfort from his wife. Mrs Ramsay being overburdened and stifled by her responsibilities as a wife to her husband is purposefully underlined at many junctures of the novel. In addition, the conflicts between the husband and wife in Ramsay household are primarily shown to be the response to $\mathrm{Mr}$ Ramsay's agnosticism.

If we look at the diaries and letters written in Woolf's early life it is apparent that the "barrenness" with which she associates Mr Ramsay is a symptom of her father, Leslie Stephen as well. (see Table 8) This image of "barrenness" is thwarted when contrary to the cruel father imaged depicted by Mrs Ramsay and narrative, we see $\mathrm{Mr}$ Ramsay grieving over the death of his wife. (Gaipa) Woolf clearly seems to be targeting Leslie Stephen with the image of Mr Ramsay assuming the agnostic stance in the section "The Window" which is strikingly similar to the image Woolf depicted about her father in her 1893 collection of essays, An Agnostic's Apology and Other Essays.

The fact that Woolf idealised her mother, Julia Stephen as a divine figure poised against her father's materialism resonates with the children's repulsion from $\mathrm{Mr}$ Ramsay in To the Lighthouse. The readers are influenced to believe that $\mathrm{Mr}$ Ramsay has a negating influence both on the plot as well as his children, often depicted as "short sighted." However, as the novel ends, Mr Ramsay is shown looking flipside at the isle from the sea with "his long sighted eyes." (p.434)

When the textual samples are placed vis-a-vis the diaries and letters samples, the results turn out to be similar for most of the integral ideas. Let us have a look at the results obtained after applying Fillmore's Frame Semantics on the novel as well as her personal writings:

Table.1: Fillmore's Frame Elements in To the Lighthouse (1927) and Diaries (1925-1927)

\begin{tabular}{|c|c|c|c|c|}
\hline S.No. & $\begin{array}{c}\text { Frame Elements in To The } \\
\text { Lighthouse }\end{array}$ & $\begin{array}{c}\text { Frame } \\
\text { Elements } \\
\text { in Diaries }\end{array}$ & Lexical Units & Comment \\
\hline 1. & $\begin{array}{l}\text { "It annoyed her, this phrase- making, } \\
\text { and she said to him, in a matter of } \\
\text { fact way, that it was a perfectly } \\
\text { lovely }\end{array}$ & $\begin{array}{l}\text { "Yet I'm } \\
\text { the only } \\
\text { woman in } \\
\text { England }\end{array}$ & $\begin{array}{l}\text { "he would have } \\
\text { written better } \\
\text { books } \\
\text { if he had }\end{array}$ & $\begin{array}{l}\text { Woolf's subconscious use of words indicate } \\
\text { that her personal life is indeed a great part } \\
\text { of her fiction as } \\
\text { she writes what she likes. When }\end{array}$ \\
\hline
\end{tabular}




\begin{tabular}{|c|c|c|c|c|}
\hline & $\begin{array}{l}\text { evening. And what was he } \\
\text { groaning about, she asked, } \\
\text { half laughing, half } \\
\text { complaining, for she guessed } \\
\text { what he was thinking-he } \\
\text { would have written better } \\
\text { books if he had not } \\
\text { married." } \\
\text { (p.335) }\end{array}$ & $\begin{array}{l}\text { free to write what I } \\
\text { like." (p.201) } \\
\text { (22nd September, 1925) }\end{array}$ & $\begin{array}{l}\text { not } \\
\text { married" and } \\
\text { "write } \\
\text { what I like." }\end{array}$ & $\begin{array}{l}\text { Woolf associates the idea of writing } \\
\text { books to marriage, she subtly hints } \\
\text { that the issues of marriage restrict } \\
\text { her from heightening her literary } \\
\text { career. }\end{array}$ \\
\hline 2. & $\begin{array}{l}\text { "But he could not speak to } \\
\text { her. He could not interrupt } \\
\text { her." (p.332) }\end{array}$ & $\begin{array}{l}\text { "This one is } \\
\text { Tothe } \\
\text { Lighthouse. } \\
\text { I am now } \\
\text { writing as } \\
\text { fast and } \\
\text { freely as I } \\
\text { have } \\
\text { written } \\
\text { the whole of } \\
\text { my } \\
\text { more } \\
\text { twenty } \\
\text { times more } \\
\text { so- than any } \\
\text { novel yet." } \\
\text { (p.205) } \\
\text { (23rd } \\
\text { February, } \\
1926)\end{array}$ & $\begin{array}{l}\text { "he could } \\
\text { not speak to } \\
\text { her" } \quad \text { and } \\
\text { "writing } \\
\text { fast as } \\
\text { freely" }\end{array}$ & $\begin{array}{l}\text { Although the novel majorly throws } \\
\text { light on the issues of marriage, it is } \\
\text { interesting to observe that Woolf's } \\
\text { Diaries cautiously lessens the } \\
\text { mention of her husband Leonard } \\
\text { Woolf in order to avoid subjective } \\
\text { Effects on the novel. Woolf's } \\
\text { affirmation that she wrote the novel } \\
\text { with an ease confirms that the } \\
\text { incidents shown in the novel are } \\
\text { inspired from her own life. The } \\
\text { paradox between "could not speak" } \\
\text { and "writing as fast and freely" is } \\
\text { thus resolved. }\end{array}$ \\
\hline
\end{tabular}

\section{CONCLUSION}

The association between $\mathrm{Mr}$ and Mrs Ramsay proves that matrimony is not a assurance of established and vigorous relationship between the wedded couple no matter how hard they attempt to pretend, which further brings us to the fact that although Woolf stresses that she shared a great bond with her husband, Leonard Woolf, it might be the absence of warmth that the couple acknowledged, leading to her several nervous breakdowns immediately after her marriage, as the reflection of her personal life, To the Lighthouse with the use of various negatively evocative lexical expressions as well as harsh characterization of both the couples, underline that the author had a terribly negative opinion about the notion of marriage.

\section{REFERENCES}

[1] Bell, Anne Olivier, ed. The Diary of Virginia Woolf. Houghton Mifflin Harcourt, 1977. Geeraerts, Dirk. Theories of Lexical Semantics. New York : Oxford University Press, 2010.

[2] Rundquist, Eric. "“How is Mrs Ramsay Thinking? The Semantic Effects of Consciousness Presentation Categories within Free Indirect Style."' (2014).

[3] Woolf, Virginia. Moments of being. Houghton Mifflin Harcourt, 1985

[4] Woolf, Virginia. "To the Lighthouse" Collected Novels of Virginia Woolf. Palgrave Macmillan, London, 1992. 177334. 